FRONTLINE MEDICAL SCIENCES AND PHARMACEUTICAL JOURNAL

(ISSN - 2752-6712)

VOLUME 02 ISSUE 01 Pages: 17-24

SJIF IMPACT FACTOR (2021: 5.14)

OCLC - 1272874727 METADATA IF - 6.986

Crossref do

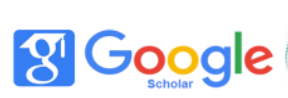



InDExing (5) WorldCat fô MENDELEY

Publisher: Frontline Journals

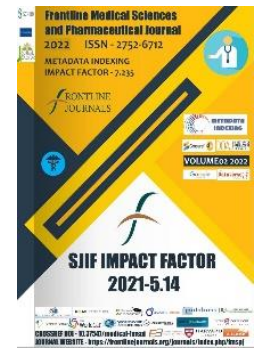

Journal Website: https://frontlinejournal s.org/journals/index.ph $\mathrm{p} / \mathrm{fmspj}$

Copyright: Original content from this work may be used under the terms of the creative commons attributes 4.0 licence.
Research Article

\section{INDICATORS OF THE EXTERNAL RESPIRATORY SYSTEM AND CARDIAC ACTIVITY IN ADOLESCENTS}

Submission Date: January 07, 2022, Accepted Date: January 17, 2022,

Published Date: January 27, 2022

Crossref doi: https://doi.org/10.37547/medical-fmspj-02-01-03

Sh. Kurtieva

Researcher, Center for the development of professional qualifications of medical workers, Tashkent, Uzbekistan

\title{
Abstract
}

The purpose of this study was to identify the features of the state of the respiratory system and cardiac activity in children with autonomic dysfunctions, depending on gender. We examined 243 adolescents 12 18 years old with clinically and laboratory-instrumental confirmed dysfunction of the autonomic nervous system - autonomic dystonia syndrome. It was found that signs of cardiac abnormalities are more often observed in adolescents with SVD with a history of perinatal pathology, mostly in males. The risk of developing violations of bronchial patency was identified in adolescents with SVD with a history of perinatal pathology, to a greater extent in females.

\section{KeYwords}

Adolescents, autonomic disorders, perinatal pathology. 


\section{INTRODUCTION}

Vegetative disorders in children occur in $25-80 \%$ of cases, and in 17 - 20\% of cases they progress, transforming into diseases such as ischemic heart disease, hypo- and hypertension, bronchial asthma, gastric ulcer and duodenal ulcer [3]. The prevalence of this pathology among noninfectious diseases of childhood and adolescence ranges from 29.1 to $75 \%$ of cases [4].

The leading role of the autonomic nervous system in the formation of pathology of the cardiovascular system in children has been proven, and dysfunction of the autonomic nervous system is considered as a disease of adaptation, breakdown of neuroendocrine autonomic regulation of the heart and blood vessels [2]. In cases where the active factor exceeds the adaptive capabilities of the cardiovascular system, a pathological process occurs, including both functional and structural disorders. The cardiovascular and respiratory systems, due to their "indicator" advantages, are given a priority role in assessing the adaptive capabilities of the whole organism $[1,5]$.

\section{The MAIN RESULTS AND FINDINGS}

To reveal the peculiarities of the state of the respiratory system and cardiac activity in children with autonomic dysfunctions, depending on gender.

This work is based on the results of clinical and functional studies of the cardiovascular and respiratory systems in adolescents with SVD, depending on the presence of perinatal pathology. We examined 243 adolescents 12-18 years old with clinically and laboratoryinstrumental confirmed dysfunction of the autonomic nervous system - autonomic dystonia syndrome (SVD). The average age of the clinical manifestation of SVD in girls was $12.2 \pm 1.8$ years, in boys $-13.5 \pm 2.1$ years.

In the course of the study, groups of adolescents with SVD were formed, depending on gender and a history of perinatal pathology of the nervous system (PPNS), Group 1 consisted of 53 (21.8\%) adolescent boys with PPNS, Group 2 - 34 (14.0\%) adolescent boys without PPNS, 3 groups accounted for 107 (44.0\%) adolescent girls with PPNS and group 4 - 49 (20.2\%) adolescent girls without PPNS. (table 1) 
FRONTLINE MEDICAL SCIENCES AND PHARMACEUTICAL JOURNAL

(ISSN - 2752-6712)

VOLUME 02 ISSUE 01 Pages: 17-24

SJIF IMPACT FACTOR (2021:5.14)

OCLC - 1272874727 METADATA IF - 6.986

Table 1.

Distribution of patients with SVD into groups, depending on the presence of a previous PPNS in the anamnesis.

\begin{tabular}{|c|r|r|c|}
\hline \multicolumn{2}{|c|}{ Groups } & $\mathrm{n}$ & $\%$ \\
\hline I group & $\begin{array}{c}\text { adolescent } \\
\text { boys with PPNS }\end{array}$ & 53 & $21,81 \%$ \\
\hline II group & $\begin{array}{c}\text { adolescent } \\
\text { boys without PPNS }\end{array}$ & 34 & $13,99 \%$ \\
\hline $\begin{array}{c}\text { III } \\
\text { group }\end{array}$ & $\begin{array}{c}\text { teenage girls } \\
\text { with PPNS }\end{array}$ & 107 & $44,03 \%$ \\
\hline IV & $\begin{array}{c}\text { teenage girls } \\
\text { wroup }\end{array}$ & 49 & $20,16 \%$ \\
\hline Total & & 243 & $100,00 \%$ \\
\hline
\end{tabular}

Note: SVD - autonomic dystonia syndrome.

PPNS-perinatal lesions of the nervous system.

ECG registration was carried out on a 6-TEK-3 apparatus (2003) in 12 conventional leads, at a paper speed of $50 \mathrm{~mm} / \mathrm{s}$, the ECG was recorded at rest, in the supine position.

Respiratory function was assessed using the "Valenta" hardware-software complex. The following indicators were investigated:

- Vital capacity of the lungs (VC) consisting of the reserve volume of inspiration, reserve volume of expiration, tidal volume, in liters.
- Forced vital capacity of the lungs (FVC) - the amount of air that can be exhaled during forced exhalation within $1 \mathrm{~s}$ after maximum inhalation, in percentage. - FEV1 - forced expiratory volume in one second - expired air volume in one second of forced expiration.

- The Typhno index is the forced expiratory volume in $1 \mathrm{sec}$ as a percentage of the proper VC.

The statistical data were processed using the STATISTICA 6.0 application package (StatSoft Inc., USA). 
FRONTLINE MEDICAL SCIENCES AND PHARMACEUTICAL JOURNAL

(ISSN - 2752-6712)

VOLUME 02 ISSUE 01 Pages: 17-24

SJIF IMPACT FACTOR (2021: 5.14)

OCLC - 1272874727 METADATA IF - 6.986

Publisher: Frontline Journals

For the studied parameters, the following indicators were determined: mean value $(M)$, standard error of the mean (m); if necessary, the median (Me) and interquartile range (25\% percentile and $75 \%$ percentile) of the trait are indicated. To compare the quantitative characteristics of two independent groups, a nonparametric method was used - the calculation of the Mann-Whitney U-test, for 3 or more groups - the Kruskal-Wallis ANOVA method. The assessment of qualitative parameters was carried out in absolute and relative values (\%), to compare qualitative characteristics in two independent groups, the $\chi 2$ test was used, for small samples - Fisher's exact test, for multiple comparisons - Cochran's Q-test. Differences with a $95 \%(p<0.05)$ significance level were considered statistically significant.

In order to study the state of cardiac activity in children with autonomic disorders, electrocardiographic parameters were studied in adolescents with SVD. Of the total number of adolescents studied, 79 (32.5\%) had sinus bradycardia, the second most common was an increase in the T wave - in $30.5 \%$ of cases (Fig. 1).

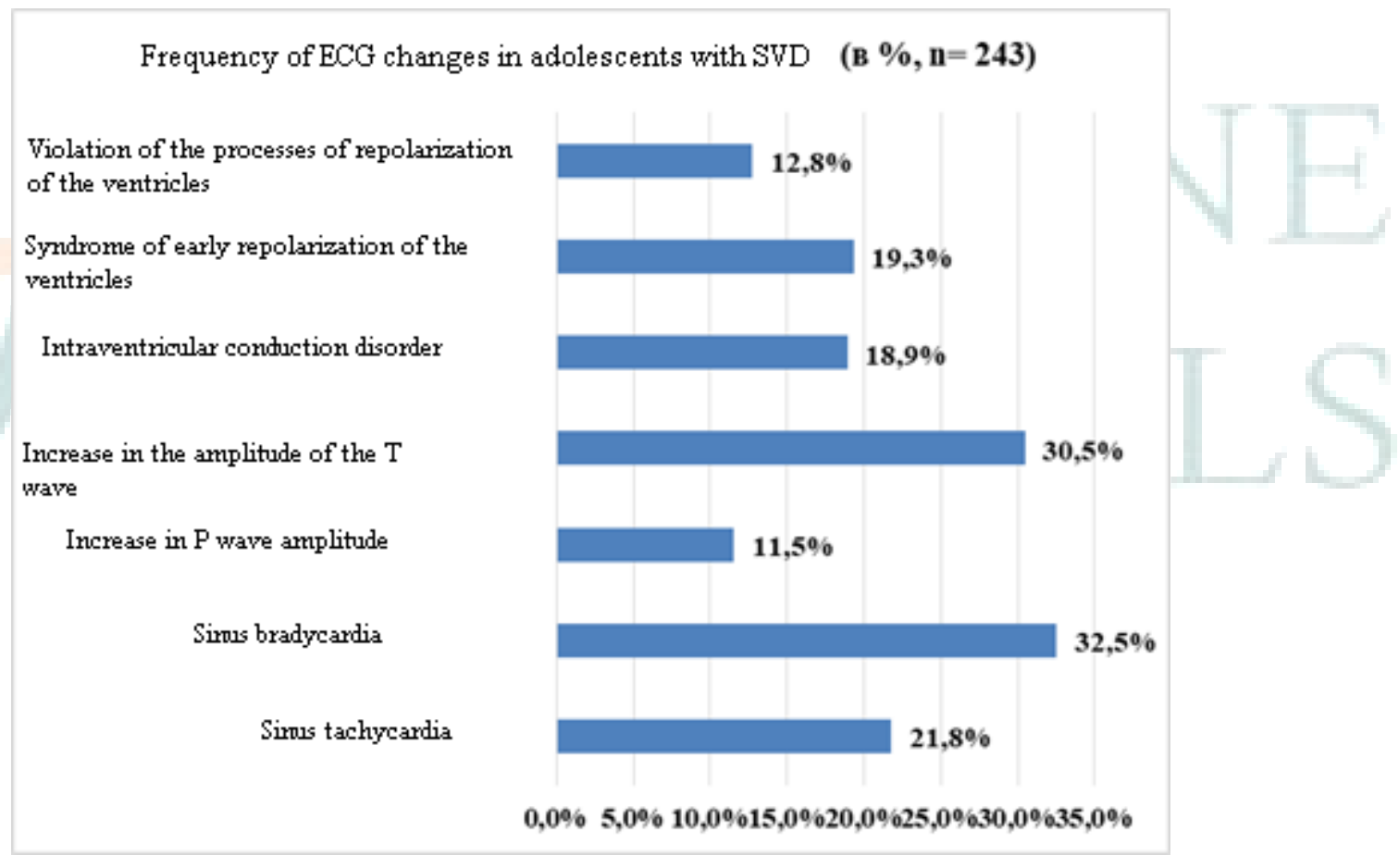

Fig. 1. The frequency of ECG changes in adolescents with SVD.

Sinus bradycardia in adolescents in groups I and III was more common than in groups II and IV (22.6\% and $25.2 \%$ versus $14.7 \%$ and $18.4 \%$, respectively). 
FRONTLINE MEDICAL SCIENCES AND PHARMACEUTICAL JOURNAL

(ISSN - 2752-6712)

VOLUME 02 ISSUE 01 Pages: 17-24

SJIF IMPACT FACTOR (2021:5.14)

OCLC - 1272874727 METADATA IF - 6.986

\section{Crossref doi) 81 Google \\ 倠 \\ Publisher: Frontline Journals}

At the same time, an increase in the $\mathrm{T}$ wave was observed in $22(41.5 \%)$ adolescents in group I compared with group II - 5 (14.7\%); p1 <0.001. Rhythm disturbances in the form of sinus tachycardia were observed in $27(25.2 \%)$ in group III and in 12 (22.6\%) patients in group I.

A greater percentage of patients with impaired intraventricular conduction was observed in group III - 28 (26.2\%), in group II this symptom was found in $17.0 \%$ of cases. In group III, lengthening of the PQ interval (atrioventricular block of I degree), high and pointed T waves were recorded (Table 1)

Table 1.

The frequency of ECG changes in adolescents with SVD, depending on gender and a history of perinatal pathology.

\begin{tabular}{|c|c|c|c|c|c|c|c|c|}
\hline \multirow{2}{*}{ ECG indicators } & \multicolumn{2}{|c|}{$\begin{array}{c}\text { Group I (n = } \\
\text { 53) }\end{array}$} & \multicolumn{2}{c|}{$\begin{array}{c}\text { Group II (n } \\
\text { 34) }\end{array}$} & \multicolumn{2}{c|}{$\begin{array}{c}\text { Group III (n = } \\
\text { 107) }\end{array}$} & \multicolumn{2}{c|}{$\begin{array}{c}\text { Group IV (n = } \\
\text { 49) }\end{array}$} \\
\cline { 2 - 10 } & $\mathbf{n}$ & $\mathbf{9}$ & $\mathbf{n}$ & $\mathbf{\%}$ & $\mathbf{n}$ & $\mathbf{\%}$ & $\mathbf{n}$ & $\mathbf{\%}$ \\
\hline Sinus tachycardia & 12 & $22,6 \%$ & 5 & $14,7 \%$ & 27 & $25,2 \%$ & 9 & $18,4 \%$ \\
\hline $\begin{array}{c}\text { Sinus } \\
\text { bradycardia }\end{array}$ & 15 & $28,3 \%$ & 7 & $20,6 \%$ & 48 & $44,9 \%$ & 9 & $18,4 \%$ \\
\hline $\begin{array}{c}\text { Increase in the } \\
\text { amplitude of the } \\
\text { P wave }\end{array}$ & 6 & $11,3 \%$ & 8 & $23,5 \%$ & 4 & $3,7 \%$ & 10 & $20,4 \%$ \\
\hline $\begin{array}{c}\text { Increase in the } \\
\text { amplitude of the } \\
\text { T wave }\end{array}$ & 22 & $41,5 \%$ & 5 & $14,7 \%$ & 39 & $36,4 \%$ & 8 & $16,3 \%$ \\
\hline $\begin{array}{c}\text { Intraventricular } \\
\text { conduction } \\
\text { disorder }\end{array}$ & 9 & $17,0 \%$ & 3 & $8,8 \%$ & 28 & $26,2 \%$ & 6 & $12,2 \%$ \\
\hline $\begin{array}{c}\text { Syndrome of } \\
\text { early } \\
\text { repolarization of } \\
\text { the ventricles }\end{array}$ & 8 & $15,1 \%$ & 2 & $5,9 \%$ & 29 & $27,1 \%$ & 8 & $16,3 \%$ \\
\hline $\begin{array}{c}\text { Violation of } \\
\text { repolarization } \\
\text { processes }\end{array}$ & 7 & $13,2 \%$ & 1 & $2,9 \%$ & 22 & $20,6 \%$ & 1 & $2,0 \%$ \\
\hline
\end{tabular}


FRONTLINE MEDICAL SCIENCES AND PHARMACEUTICAL JOURNAL

(ISSN - 2752-6712)

VOLUME 02 ISSUE 01 Pages: 17-24

SJIF IMPACT FACTOR (2021:5.14)

OCLC - 1272874727 METADATA IF - 6.986

\section{Crossref doi

The syndrome of early repolarization of the ventricles, represented by a scaphoid deformity of a segment with a slight displacement of its relative isoline, was detected in $29(27.1 \%)$ in group III and in $15.1 \%$ of cases in group I, which may indicate the peculiarities of metabolic processes in the developing myocardium in this contingent. children. Violation of ventricular repolarization, represented by a shortening of the PQ interval, was detected in $20.6 \%$ of patients in group III and in $13.2 \%$ of patients in group I.

Respiratory function was assessed by spirography. So, in group III, violations of bronchial patency were observed, as indicated by such indicators of spirography as VC, FVC, FEV and Tiffno's index. These indicators were reduced and amounted to $63.7 \%$ and $61.4 \%$, respectively, which is 1.2 times lower in comparison with these indicators of group II $(73.4 \%$ and $71.6 \%$, respectively); $\mathrm{p} 1<0.01$.

In group I, the VC indicator (68.3\%), although it differed from this indicator in group II (73.4\%) (p1 <0.01), however, it was lower than in group IV $(70.1 \%)(p<0.01)$. These violations were reflected in the FEV 1 , which was also the smallest in group III, 62.5\%; p1 <0.001, compared with group II - 72.7\%. (table 2).

\section{Table 2.}

Spirography indicators in adolescents with SVD, depending on gender. (Me [25q; 75q])

\begin{tabular}{|c|c|c|c|c|c|c|c|c|c|c|}
\hline \multirow[t]{2}{*}{$\begin{array}{c}\text { FVD } \\
\text { indicators }\end{array}$} & $\begin{array}{l}\text { Group I } \\
(n=53)\end{array}$ & \multirow{2}{*}{$\begin{array}{c}p \\
1-2 \\
\leq\end{array}$} & $\begin{array}{l}\text { Group II } \\
(n=34)\end{array}$ & \multirow{2}{*}{$\begin{array}{c}p \\
2-3 \\
\leq\end{array}$} & $\begin{array}{l}\text { Group III } \\
(n=107)\end{array}$ & \multirow{2}{*}{$\begin{array}{c}p \\
3-4 \\
\leq\end{array}$} & \multirow{2}{*}{$\begin{array}{c}\begin{array}{c}\text { Group IV } \\
(n=49)\end{array} \\
4\end{array}$} & \multirow{2}{*}{$\begin{array}{c}p \\
4-1 \\
\leq\end{array}$} & \multirow{2}{*}{$\begin{array}{c}p \\
4-2 \\
\leq\end{array}$} & \multirow{2}{*}{$\begin{array}{c}p \\
3-1 \\
\leq\end{array}$} \\
\hline & 1 & & 2 & & 3 & & & & & \\
\hline VC (\%) & $\begin{array}{c}68,3 \\
{[68,0 ;} \\
69,3]\end{array}$ & 0,01 & $\begin{array}{c}73,4 \\
{[72,1 ;} \\
75,3]\end{array}$ & 0,001 & $\begin{array}{c}63,7 \\
{[61,7 ;} \\
65,9]\end{array}$ & 0,001 & $\begin{array}{c}70,1 \\
{[69,0 ;} \\
71,3]\end{array}$ & 0,01 & 0,01 & 0,001 \\
\hline FVC (\%) & $\begin{array}{c}64,1 \\
{[64,0 ;} \\
65,1]\end{array}$ & 0,01 & $\begin{array}{c}71,6 \\
{[70,0 ;} \\
73,1]\end{array}$ & 0,001 & $\begin{array}{c}61,4 \\
{[60,8 ;} \\
63,1]\end{array}$ & 0,01 & $\begin{array}{c}65,9 \\
{[64,9 ;} \\
67,1]\end{array}$ & 0,01 & 0,01 & 0,01 \\
\hline FEV 1 (\%) & $\begin{array}{c}68,9 \\
{[67,2 ;} \\
69,3]\end{array}$ & 0,01 & $\begin{array}{c}72,7 \\
{[71,7 ;} \\
73,9]\end{array}$ & 0,001 & $\begin{array}{c}62,5 \\
{[61,3 ;} \\
63,6]\end{array}$ & 0,01 & $\begin{array}{c}69,1 \\
{[68,6 ;} \\
69,7]\end{array}$ & 0,01 & 0,01 & 0,01 \\
\hline $\begin{array}{r}\text { Tiffeneau } \\
\text { index (\%) }\end{array}$ & $\begin{array}{c}81,8 \\
{[80,9 ;} \\
83,3]\end{array}$ & 0,01 & $\begin{array}{c}85,3 \\
{[85,8 ;} \\
87,5]\end{array}$ & 0,01 & $\begin{array}{c}70,7 \\
{[70,5 ;} \\
71,5]\end{array}$ & 0,001 & $\begin{array}{c}81,2 \\
{[80,6 ;} \\
82,4]\end{array}$ & 0,01 & 0,01 & 0,001 \\
\hline
\end{tabular}

Note: $p$ is the statistical significance of the difference in indicators. 
FRONTLINE MEDICAL SCIENCES AND PHARMACEUTICAL JOURNAL

(ISSN - 2752-6712)

VOLUME 02 ISSUE 01 Pages: 17-24

SJIF IMPACT FACTOR (2021:5.14)

OCLC - 1272874727 METADATA IF - 6.986

The lowest Tiffneau index - an indicator of the ratio of the volume of air exhaled in the first second with the fastest expiration to the vital capacity of the lungs, was observed in patients of group III (70.7\%) compared with group II $(85.3 \%)(\mathrm{p} 1<0.001)$ and with groups I and IV (81.8\% and 81.2\%) (p1<0.001).

\section{Conclusion}

Signs of cardiac dysfunction are more often observed in adolescents with SVD with a history of perinatal pathology, mostly in males. The risk of developing violations of bronchial patency was identified in adolescents with SVD with a history of perinatal pathology, to a greater extent in females.

\section{ReFERENCES}

1. T.V. Agafonkina Assessment of the state of functional reserves of the cardiorespiratory system in persons of different ages / T.V. Agafonkina, V.N. Diomidova // Health care of Chuvashia. 2012. - No. 4. - P. 16-19.

2. Grigoriev K.I. Syndrome of vegetative dystonia in children and adolescents / KI Grigoriev, EL Povazhnaya, AL Solovieva // Nurse - 2013 -№7 -p. 28-32

3. Kushnir S.M. Vegetative dysfunction and vegetative dystonia / S.M. Kushnir, L.K. Antonova - Tver, 2007 - 215 p.

4. Morozova O.G. Vegetative dysfunctions in general somatic practice / O.G. Morozova
// Health of Ukraine /, 2008, №3. -P. 5152.

5. Ostropolets, S.S. Pulmonological aspects of cardiac pathology in children / S.S. Ostropolets // Help the pediatrician. 2009. - No. 4 (19). - P. 47-49.

6. Куртиева, Ш. (2021). CHANGES IN ELECTROENCEPHALOGRAM INDICATORS IN ADOLESCENTS WITH VEGETATIVE DYSFUNCTION. УЗБЕКСКИЙ МЕДИЦИНСКИЙ ЖУРНАЛ, (SPECIAL 3).

7. Куртиева, Ш., Иноятова, Ф. И., \& Гафуров, Б. Г. (2021). ХОЗИРГИ ЗАМОН ЎСМИРЛАРИДА ФУНКЦИОНАЛ КАРДИОПАТИЯ СИНДРОМИНИ САБАБЛАРИ. Журнал теоретической и клинической медицины, (1), 39-42.

8. Мухамедова, М. Г., Куртиева, Ш. А., \& Назарова, Ж. А. (2020). СИНДРОМ ФУНКЦИОНАЛЬНОЙ КАРДИОПАТИИ У СОВРЕМЕННЫХ ПОДРОСТКОВ. In П84 Профилактическая медицина-2020: сборник научных трудов Всероссийской научно-практической конференции с международным участи-ем. 18-19 ноября 2020 года/под ред. АВ Мельцера, ИШ Якубовой. Ч. 2.СПб.: Изд-во СЗГМУ им. ИИ Мечникова, 2020.-304 c. (p. 105).

9. Юлдашева, М. М., Маджидова, Ё. Н., Гафуров, Б. Г., Назарова, Ж. А., Доронина, О. Б., \& Доронин, Б. М. (2019). Особенности церебральной венозной гемодинамики при острых нарушениях мозгового кровообращения. Практическая медицина, 17(7). 
FRONTLINE MEDICAL SCIENCES AND PHARMACEUTICAL JOURNAL

(ISSN - 2752-6712)

VOLUME 02 ISSUE 01 Pages: 17-24

SJIF IMPACT FACTOR (2021: 5.14)

OCLC - 1272874727 METADATA IF - 6.986

Crossref dil google

\%

10. Гафуров, Б. Г., Аликулова, Н. А., \& Назарова, Ж. А. (2019). Роль церебральной венозной дисгемии в формировании хронической недостаточности мозгового кровообращения. In Фундаментальные основы инновационного развития науки и образования (рр. 223-241).

11. Аликулова, Н. А., Назарова, Ж. А., \& Рахматова, С. Н. (2018). Гендерные различия когнитивных функций при цереброваскулярной патологии. World science, $1(10$ (38)).

12. Назарова, Ж. А., \& Бахадирханов, М. М. (2019). Особенности церебральной венозной гемодинамики при острых нарушениях мозгового кровообращения. Вестник экстренной медицины, 12(6).

13. Назарова, Ж. А. (2019). Оценка клинического и нейрофизиологического состояния когнитивных функций при венозной церебральной дисфункции. Справочник врача общей практики, (1), 33-39. 